\title{
EU Eastern Partnership and New Challenges for Europe
}

The Jean Monnet Centre of Excellence at the University of Latvia hosted a Jean Monnet Conference, "EU Eastern Partnership from Capacities to Excellence: Strengthening Research, Regional and Innovation Policies in the Context of Horizon 2020" from 11-13 June 2014. The conference was an initiative within the framework of the European Commission Jean Monnet Programme and focused on European Research Area and Eastern Partnership (EaP) Roadmap. It covered issues related to the EU current Eastern Partnership policy initiatives and the good practices of different EU Member States and Eastern Partnership countries; it also took into account the outcomes of the Third EU Eastern Partnership Summit in Vilnius (28-29 November 2013). The event was generously supported by the European Commission, its Representation in Latvia, and the Ministry of Foreign Affairs of Latvia.

The conference was composed of panels, round-table discussions and assemblies, involving representatives from the European Commission, NATO, the EU and EaP national policy-making bodies, policy makers and a broad research community, aiming to strengthen research, regional and innovation policies in the context of Horizon 2020.

The publication emphasizes that in the $21^{\text {st }}$ century, societies with different and complex cultural identities and beliefs are forced to interact closely. In the EU Member States, just as in any Eastern Partnership country, discussion is taking place on what will be the political and scientific response to the challenges in EU external relations and Eastern Partnership policies. The Eastern Partnership initiative is an important EU policy striving to bring democracy, stability and prosperity to the partner countries. In the last five years, the EaP has produced somewhat mixed results and been a disappointment in many cases. Structural policy weaknesses and different socio-economic realities in the EaP countries notwithstanding, the major challenge to the successful implementation of the EaP comes from Russia's policy related to the geopolitical dominance in its shared neighborhood with the European Union.

Articles in the publication suggest that to achieve the needed transformations in the future, the EaP could benefit from a fresh start and the EU from an enlarged circle of friends at its eastern borders. 
The discussion is the result of increasing pressure and suggested solutions coming from both scientists as well as politicians who are expected to provide objective and evident-based decisions. While we do not yet have clear answers on how to cope with these many different challenges, some solutions could be found by thinking across the boundaries of economics, technology, cultural understanding, natural sciences and innovation.

All the EU Member States and Eastern Partnership countries are following the ambitious Horizon 2020 initiative. Innovation, research and development, education, regional policies are important flagship initiatives.

Solidarity is one of the fundamentals of European integration, and very often this is the only opportunity to get the Eastern Partnership countries out of economic, social and even political difficulties, to maintain their stability and keep the broad benefits of the Association Agreements.

Research, innovation and education have a key role to play in promoting growth and guaranteeing equal opportunities and social cohesion. The above-mentioned aspects are currently subject of intensive studies aimed at contributing to the future of the EU external policies in relation to the Eastern Partnership to achieve the Eastern Partnership.

This publication is the second contribution of the Jean Monnet Centre of Excellence to The Baltic Journal of European Studies after the June 2014 issue of the Baltic Journal of European Studies. The current collection of studies is dedicated to different aspects of the EU Eastern Partnership policy and offers the views of academia, senior and young researchers and practitioners from a variety of disciplines and different countries. Many hold views which illustrate important clashes of different opinions that occur in the debate on themes such as research and education, innovation, competitiveness, social and regional cohesion, and the political process. The articles provide recommendations and suggestions for policy makers at local, national, and regional levels.

I would like to extend my sincere appreciation to all the contributing authors and special thanks to the journal's Editorial Board for reviewing the articles submitted for publication.

Tatyana Muravska

Director, Jean Monnet Centre of Excellence University of Latvia 